\title{
Recessions and Tax-Cuts: Economic Cycles' Impact on Individual Giving, Philanthropy, and Higher Education
}

Received (in revised form): September 26, 2006

\section{Noah D. Drezner}

is an advanced Ph.D. candidate in higher education in the Policy, Management, and Evaluation Division at the University of Pennsylvania Graduate School of Education in Philadelphia, Pennsylvania. He currently holds degrees from the University of Rochester (B.S.) and the University of Pennsylvania (M.S.Ed.). His research interests include philanthropy within minority and special serving institutions and the exploration of how minority serving institutions add to the civic literacy of the nation. Recently, he published Thurgood Marshall: A study of philanthropy through racial uplift in an edited volume Uplifting a People: African American Philanthropy and Education by Marybeth Gasman and Katherine V. Sedgwick (Peter Lang, 2005; winner of the Association for Fundraising Professional's Skystone Ryan Prize for Research on Fundraising and Philanthropy) and "Advancing Gallaudet: Alumni Support for the Nation's University for the Deaf and Hardof-Hearing and its Similarities to Black Colleges and Universities" in the International Journal of Educational Advancement.

\author{
Abstract \\ Few researchers have examined how \\ individual giving to higher education is \\ effected by the economy, specifically \\ during downturns and periodic \\ changes in tax laws. Further \\ understanding the relationship between \\ the economy's cycles and philanthropic \\ giving, including the correlation of tax \\ cuts to donations, will help colleges \\ and universities better prepare for \\ future sustained downturns. Using data \\ from the American Association of \\ Fundraising Counsel's Giving USA \\ annual reports on philanthropy from \\ 1960 through 2005, the Council for

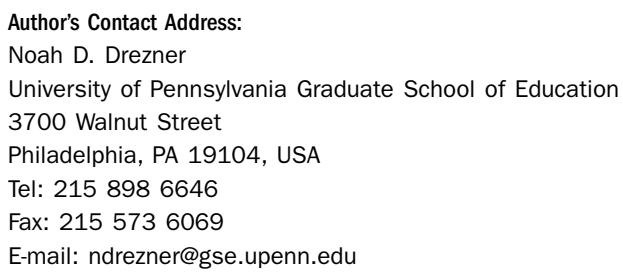

the Aid to Education's Voluntary Support of Education database, and reports from Moody's Investors Services and the Aspen Institute, this paper investigates the relationship between recessions and voluntary giving to higher education. Finally, this paper explores how federal tax policy, specifically the tax cuts in 1986 and 2001, affects giving to higher education.

International Journal of Educational Advancement (2006) 6, 289-305. doi:10.1057/palgrave.ijea.2150036

Keywords:

philanthropy, fund raising, taxes, recession, giving

\section{Introduction}

According to the American Association of Fundraising Counsel's (AAFRC) annual Giving USA reports, overall 
philanthropic gifts are tied to economy. For example, in 2001 at the beginning of the latest economic downturn, giving to education (postsecondary and other levels) totaled $\$ 32$ billion, a 0.5 percent increase over the prior year (AAFRC Trust, 2002). This was the smallest one-year increase since the mid-1970s and is remarkably small compared to the double-digit increases in giving during the late 1990s-a time of prosperity. Additionally, a March 2001 Moody's Investors Service report warned that sustained downturn would hurt fund raising, slow endowment growth, and prevent more families from affording private-college tuition (AAFRC Trust, 2002). Further understanding the relationship between the economy's cycles and philanthropic giving, including the correlation of tax cuts to donations, will help colleges and universities better prepare for future sustained downturns and the predications of the 2001 Moody's report.

\section{State of Philanthropy}

Philanthropic giving to all causes in the United States rose by over 62 percent between 1994 and 2004, to $\$ 248.52$ billion (AAFRC Trust, 2005). In the first half of this decade, between 1995 and 2000, giving grew 64.4 percent, however, as the US economy slowed in 2000 giving retrenched. For the period between 2000 and 2004, giving in constant dollars decreased from $\$ 252$ to $\$ 248.52$ billion, or a decrease of 1.24 percent (Figure 1) (AAFRC Trust, 2005). ${ }^{1}$

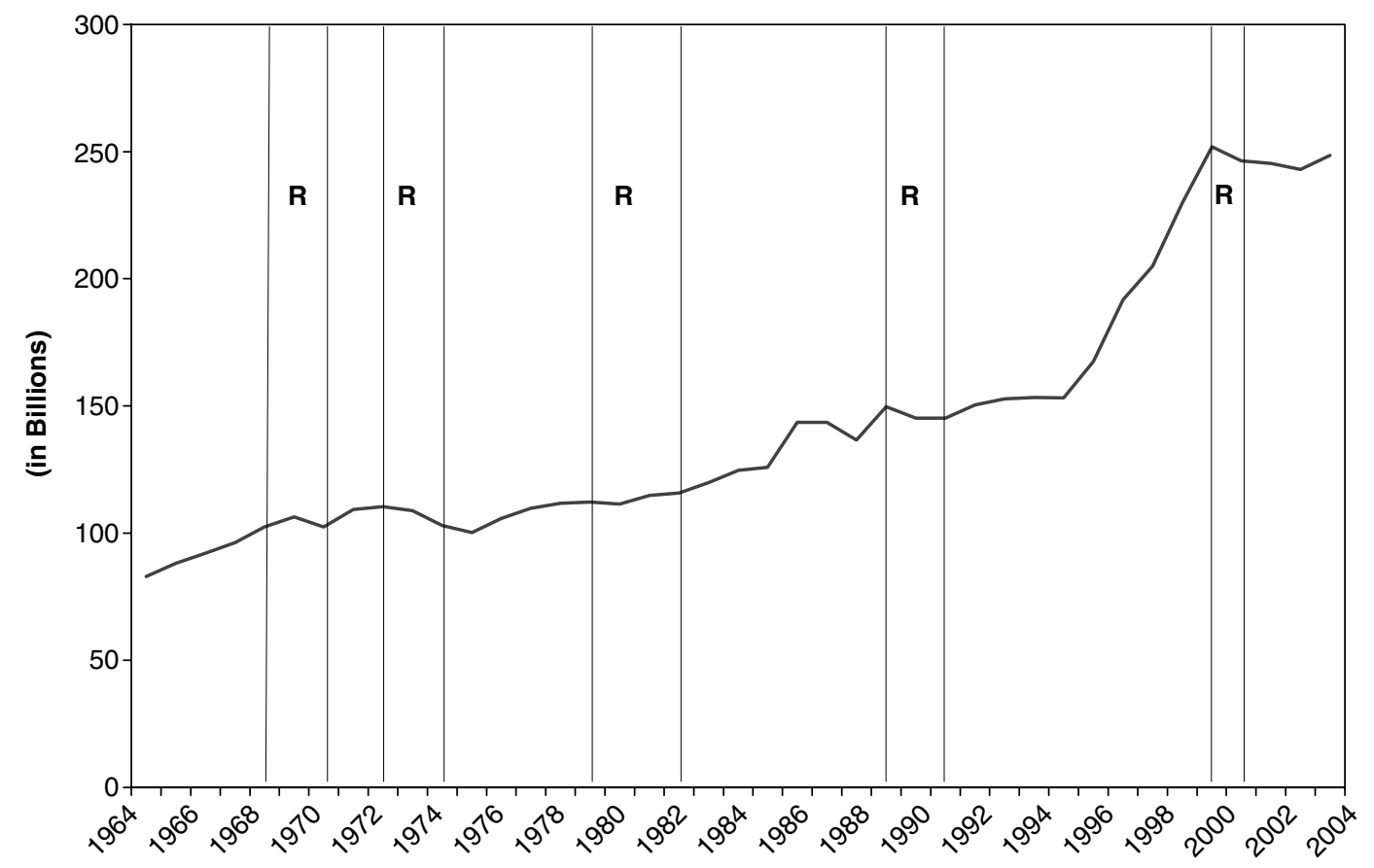

Figure 1: Total philanthropic giving in constant (2004) dollars (AAFRC Trust, 2005)

Note: ' $\mathrm{R}$ ' indicates periods of recessions in the US economy. 


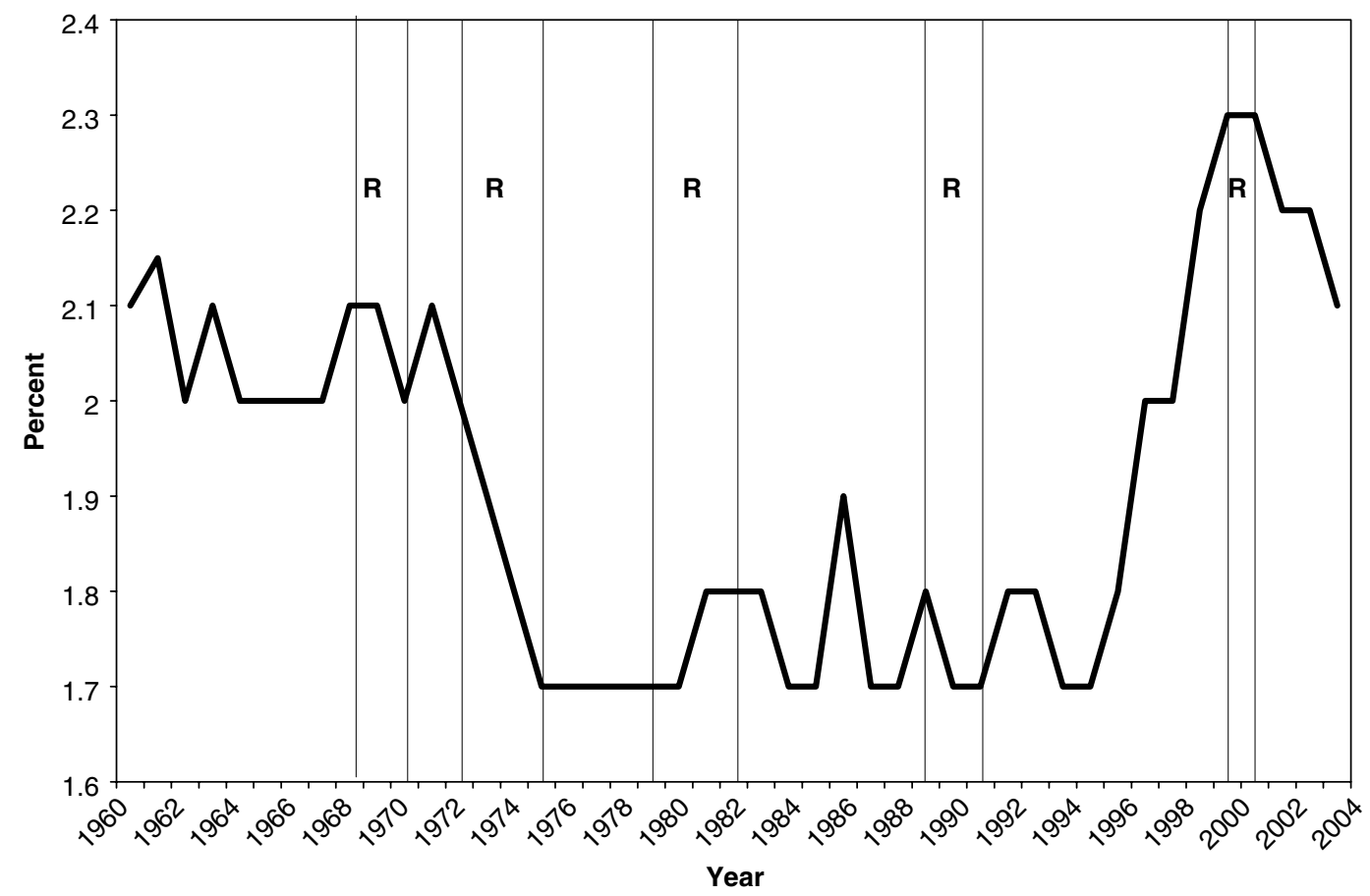

Figure 2: Giving as a percentage of GDP (1960-2004) (AAFRC Trust, 2003, 2005) Note: ' $\mathrm{R}$ ' indicates periods of recessions in the US economy.

This increase in philanthropic giving over the past decade is even more impressive when compared to economic growth. Since 1995, growth in charitable giving outpaced the robust late 1990s economy with the aggregate level of donations increasing relative to the nation's gross domestic product or GDP (see Figure 2). Even with the decline of giving as a percentage of GDP since 2000, this recent decade reversed a decline beginning in the early 1970s that resulted in giving oscillating around 1.75 percent of GDP for two decades. At a ratio of 2.1 percent in 2004 , giving as a share of GDP has returned to an approximate level at its height in the 1960s (Council of Economic Advisers, 2000). As a point of reference, Americans give their money at a higher percentage than the rest of the world. The United Kingdom is the next most generous, giving 0.7 percent of its GDP (Gaudiani, 2003).

\section{Philanthropy in higher education}

Philanthropic gifts to higher education are tied to major economic indicators (Arena, 2003). Bruce McClintock from the fund-raising consulting firm Marts \& Lundy, Inc. analyzed 1992-2001 data from the Council for Aid to Education (CAE). Using giving records from 375 institutions that consistently responded to the annual survey for 10 years, McClintock confirmed a relationship between gift designation (current unrestricted, capital, restricted endowment, and deferred) and major economic indicators. The study found 
that, adjusted for inflation, annual fund gifts, used to defray current operating costs, grew in parallel with growth in personal income. Additionally, the analysis found that gifts for capital purposes were connected to another economic indicator, the New York Stock Exchange Composite Index (Arena, 2003).

The majority of philanthropic giving comes from individuals (AAFRC Trust, 1960-2005). The importance of individual giving is further elucidated when considering the fact that philanthropic donations, as a percentage of GDP, increased sharply in the second half of the 1990s (Figure 2). The majority of this increase of giving as related to the US gross domestic product is a result of individual donations. Therefore, if the United States is to maintain the rate of giving as a percentage of GDP and avoid the declines experienced in the 1970 s, it is vital that researchers investigate individual giving in new ways. Economic Cycles clearly effect people's perception of wealth and affect the disposable income that can be put toward giving. This is, however, not the only possibility that might be at play. Some people decide to give based on the tax implications on themselves or their heirs. This paper examines how individual giving to the nation's third sector and specifically higher education is related to recessions and tax cuts. By better understanding the relationship between economic cycles' and tax cuts to donor behavior, institutions can better predict their likelihood of successfully raising funds and better strategize how to do so. The data used in this paper were collected by reviewing the American Association of Fundraising Counsel's Giving USA annual reports on philanthropy from 1960 to 2005.

\section{Significance of Philanthropy in Higher Education}

Philanthropy has been an important aspect of American higher education from the 1638 bequest of John Harvard to the Colonies' first college, through current billion dollar-plus campaigns at private and public institutions throughout the country. ${ }^{2}$ In New England's First Fruits (1643), the philanthropic history of the founding of Harvard College, the author describes citizens who "longed ... to advance learning and perpetuate it to prosperity." It is Americans' giving that has shaped higher education. In fact, Peter Dobkin Hall (1992) believes that "No single force is more responsible for the emergence of the modern university in America than giving by individuals and foundations" (p. 403). The Center for Financial Aid to Education (CFAE) has declared that over the past more than three and a half centuries gifts to the academy have "elevat[ed American higher education] to a position of excellence" (CFAE, 1973, p. 9).

While, according to Cutlip (1965), systematic and organized fund raising is a phenomenon of the American 20th century, philanthropic endeavors toward higher education were a part of colonial America by means of England. The early American economy was not able to support its own charitable activities to found and support colleges (Meuth, 1992; Ashcraft, 1995). Sustaining the 
academy, through large donations, was left to the Old World, as historian Frederick Rudolph (1962) expressed:

Individual benevolence was nonetheless in the English tradition, and the colonial colleges therefore naturally looked to it for sustenance. At first, England itself was the only reliable source of significant philanthropy. The Englishmen John Harvard and Elihu Yale, while not the founders of the colleges that took their names, were the first substantial private benefactors of collegiate education in New England. (p. 178)

The colonial colleges, such as Harvard, William and Mary, Yale, Dartmouth, Brown, Columbia, Rutgers, Princeton, Pennsylvania, and Delaware, however, received smaller gifts from donors who understood the importance of higher education from the continent as well. Cutlip (1965) cites McAnear's explanation that

The [colonial] colleges were...saved by the development of widespread popular interest in higher education, interest intense enough to impel thousands of individuals, both in America and in the British Isles, to make cash gifts aggregating a very considerable amount. (p. 5)

Many of the donations to the colonial colleges were given without any restrictions on how they could be used. Rather than invested for the future in endowments, institutions spent the gifts to build buildings, buy books, offer scholarships, and pay salaries. The purpose of these gifts was not only to further academic learning but also to educate those who attended in the region. Curti and Nash (1965) realized that these gifts were very significant to the future of educational fund raising not because of their sizein fact, they were small-but because "higher education and its philanthropic support were planted as ideas and actualities in American soil" (p. 41).

The American Revolution ended the relationship between the colonial colleges and the British educational philanthropists. Even with the limited resources for education, the 19th century was a period of increased growth in higher education. The most successful colleges were those that were the most accomplished in fund raising (Rudolph, 1962).

\section{Alumni}

The regular solicitation of alumni for support of colleges and universities did not become commonplace until after World War I. The greater participation of alumni and their donations to their alma maters resulted in a movement for alumni representation in institutions' governing boards. Cornell University was the first to begin this important cultivation step. Cultivation of alumni, including listening to and observing how their interests intersect with the needs of the university led to alumni support many different areas of the ivory tower. Donors favored bricks and mortar projects such as residence halls, libraries, student centers, or athletic centers. Alumni, however, began to establish named scholarships at this time as well. Additionally, with Harvard's Class of 1881 gift of $\$ 113,777$ in 1906 to the university, the idea of class gifts became popular (Curti and Nash, 1965).

The systematic and established approach to increase fund-raising 
effectiveness began at Harvard in 1919 with the hiring of a professional fund-raiser, John Price Jones, to handle the institution's 15-million dollar endowment campaign (Cutlip, 1965). The establishment of the Ohio State University Development Fund Association, in 1940, initiated alumni fund-raising campaigns within state-supported institutions (Meuth, 1992). Alumni support accounts for the majority of voluntary support to the academy-they provide 27.5 percent of the private donations to higher education- $\$ 6.71$ billion in the fiscal year 2004 (AAFRC Trust, 2005).

As state subvention declined, more and more public two- and four-year colleges and universities began asking for gifts from individual donors. Administrators are searching for all possible non-tax revenue sources to help meet budget requirements. Supplemental public dollars "often provide[ ] the bulk of discretionary income for publicly supported institutions, and hence has been referred to as their margin of excellence" (Garvin, 1978, p. 7).

Simply put, those universities that raise more funds have the ability to achieve more and surpass their competitors on many fronts including rankings, student enrollment and retention, grants, and faculty recruitment.

As fund raising between both public and private colleges and universities grew, increased competition for dollars resulted. Nearly 2,000 private institutions and more than 1,500 public two- and four-year colleges and universities compete with each other for the same donations. Duronion and
Loession (1991) identified this trend by offering,

The competition for private dollars, both within the field of higher education and throughout the entire nonprofit world, is more vigorous now than ever before. For some institutions, doing well in this competition is no less than a matter of survival. For all institutions, competing successfully for private support provides the money to ensure institutional growth and strength. (p. 1)

In many ways, advancement offices' success or failure translates directly into whether administrations meet their educational and institutional goals.

\section{Contemporary Philanthropy within Higher Education}

As competition increased for the common dollars among all postsecondary institutions, philanthropic support of education, specifically higher education, escalated immensely since the colonial period. This increase is noticeable within the last three decades. In fact, since 1971 alone, giving to all aspects of education, increased from $\$ 2.75$ to $\$ 33.84$ billion in 2004, an increase of 1131 percent, in current dollars (Figure 3) (AAFRC Trust, 2005).

According to the American Association of Fund Raising Council's annual report, Giving USA, donors gave $\$ 248.52$ billion to qualified nonprofit organizations within the third sector in 2004. Religious organizations received the greatest percentage of private monies (35.5 percent), while education (including all levels) received the second greatest percentage (13.1 percent). Table 1 


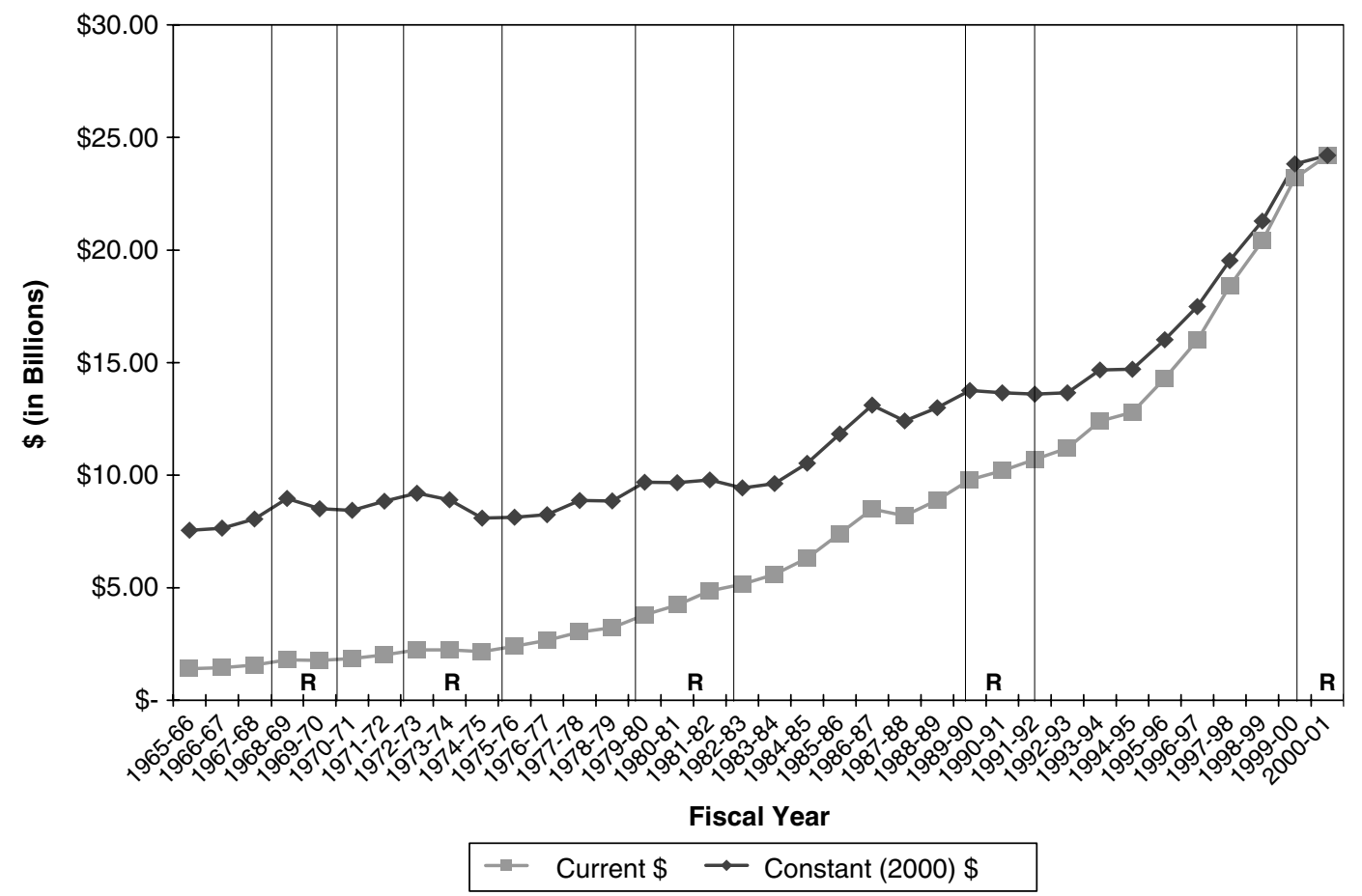

Figure 3: Estimated total voluntary support of higher education (in billions) (AAFRC Trust, 1960-2005)

Note: ' $\mathrm{R}$ ' indicates periods of recessions in the US economy.

Table 1: Uses of charitable giving in 2004 (AAFRC Trust, 2005, p. 20)

\begin{tabular}{|c|c|c|}
\hline $\begin{array}{l}\text { Type of recipient } \\
\text { organization }\end{array}$ & $\begin{array}{l}\text { Amount } \\
\text { ( } \$ \text { in billions })\end{array}$ & $\begin{array}{l}\text { Percent } \\
(\%)\end{array}$ \\
\hline Religion & 88.3 & 35.5 \\
\hline Education & 33.84 & 13.1 \\
\hline Foundations (estimate) & 24.00 & 9.7 \\
\hline Health & 21.95 & 8.8 \\
\hline Unallocated giving & 21.36 & 8.6 \\
\hline Human services & 19.17 & 7.7 \\
\hline $\begin{array}{l}\text { Arts, culture, and } \\
\text { humanities }\end{array}$ & 13.99 & 5.6 \\
\hline Public-society benefit & 12.96 & 5.2 \\
\hline Environment/animals & 7.61 & 3.1 \\
\hline International affairs & 5.34 & 2.1 \\
\hline Total dollars & 248.52 & 99.4 \\
\hline
\end{tabular}

indicates the distribution of donations to all the areas of giving identified in the study (AAFRC Trust, 2005).
Table 2: Charitable contributions to education 2002 (AAFRC Trust, 2003, p. 120)

\begin{tabular}{ll}
\hline Type of educational organization & Percent $(\%)$ \\
\hline US higher education & 62 \\
K-12 education & 8 \\
Scholarship & 8 \\
Other & 8 \\
International higher education & 7 \\
Donor-advised funds & 5 \\
Library & 2 \\
Total & 100 \\
\end{tabular}

Higher education by far receives the greatest support of all educational levels (Table 2). Within higher education, Giving USA found that giving in fiscal year 2002 dropped 
slightly for the first time since fiscal year 1988 (AAFRC Trust, 2003). This drop is associated with an overall decline in alumni giving of 13.6 percent from the past year, while contributions from other sources (corporations and foundations) remained steady. Fiscal year 2002 was the first time in more than 25 years that donations to higher education from foundations ( $\$ 6.3$ billion) surpassed alumni dollars ( $\$ 5.9$ billion). The lower giving levels by alumni are attributed to the declining economy in late 2001 and a weak stock market throughout the fiscal year, including the drop post September 11. The report found that 52 percent of gifts to higher education were given for current operations (AAFRC Trust, 2003).

The CAE's Voluntary Support for Education (VSE) study found that there was a stabilization in giving to higher education in the 2003 fiscal year, following the decline in giving in fiscal year 2002 (AAFRC Trust, 2004). The report continued that while foundation grants surpassed gifts by alumni in 2001-02, the two were equivalent, at $\$ 6.6$ billion in 2003 . This change might be due to the increased number of family foundations that emerged in the mid- and late-1990s, whose giving is replacing that of individuals (AAFRC Trust, 2004).

Alumni giving in fiscal year 2003 increased by 11.9 percent $(9.4$ percent adjusted for inflation) over the prior year, almost regaining its position prior to the latest recession. While alumni giving resurged, donations from nonalumni individuals to higher education dropped an additional 15.7 percent $(-17.6$ percent adjusted for inflation) in fiscal year 2003. This is the second such drop in nonalumni giving since fiscal year 1989. In fiscal year 2001 there was a decline of 4.1 percent $(-5.9$ percent adjusted for inflation) within this group of higher education donors (AAFRC Trust, 2004).

Giving to higher education continued to increase in fiscal years 2003 and 2004. According to the VSE survey, the 3.4 percent increase $(0.7$ percent increase adjusted for inflation) was driven by individual gifts that rose 9.7 or 6.9 percent when adjusted for inflation over the previous year. Remarkably, of individual gifts, alumni donations only rose 2 percent, which is a decline of 0.7 percent when accounting for inflation, while nonalumni contributions increased 21.5 percent (18.3 percent with inflation), fully recovering the 15.7 percent decline in fiscal year 2003 (AAFRC Trust, 2005).

\section{The Economy's Relationship to Giving}

In the most recent economic recession (2001) and in its aftermath, giving to all charitable organizations decreased (AAFRC Trust, 2002, 2003, 2004). Within education, giving reached $\$ 31.84$ billion in 2001, an increase of 0.5 percent in current dollars, however a loss of 2.3 percent when adjusted for inflation, compared to the previous year (AAFRC Trust, 2002). This retrenchment in giving to education is consistent with past recessions (Figure 1). In equivalent economic downturns between 1971 and 2000, educational philanthropy grew an average of 5.8 percent or reduced by 2.2 percent, when adjusted for inflation. In comparison, during periods of 
economic growth within the same time frame, the average rate of growth for gifts to education was 9.9 or 5.7 percent adjusted for inflation (AAFRC Trust, 2002).

The decrease in philanthropic giving during a recession is often attributed to both individuals and organizations scaling back donations because of the unstable economy and bearish stock market (Foundation Center, 2002). The New York Times documented impact of the overall decline in philanthropic giving since 2001 noting that, "Shriveling endowments [due to the declining stock market] and a new wave of philanthropic thriftiness" compelled many nonprofits to reduce their workforce and even to freeze the distribution of new grants (Strom, 2002, p. A27). Beyond the economic slow down due to the widespread internet business failures, and market volatility, the events of September 11, 2001 complicated fund-raising ability and strategy as well. The Chronicle of Higher Education noted that

Efforts to raise money lagged in the immediate aftermath of September 11 , as some institutions stopped fund-raising altogether or did not solicit from donors in the New York or Washington areas, sometimes for months. Then, late in the fiscal year, the stock market slide began, imperiling the relative wealth of donors. (Van Der Werf et al., 2002, p. A27)

The combination of recession and a national tragedy severely curtailing the immediate dollars raised and dramatically altering long-range fundraising plans designed to meet future goals and priorities (Browar and Streit, 2003).

When adjusted for inflation, data show that overall charitable giving in 2001 declined by 2.3 percent over the previous year, a decline that continued through 2003 (Figure 1). Additionally, gifts from individuals, which account for nearly three-fourths of all giving, fell by 1.7 percent when adjusted for inflation in 2001 (the latest data available) (AAFRC Trust, 2002). According to the American Association of Fundraising Council (AAFRC) Trust for Philanthropy, the authoring organization of Giving USA, philanthropic giving "fits the pattern we have seen during previous recessions. In six of the eight recession years since 1971, giving dropped by one to five percent when adjusted for inflation" (Figure 1) (Arnoult in Pulley, 2002, p. A27).

Overall giving as a percentage of the United State's gross domestic product regularly declines during recessions (Figure 2). When looking at giving to higher education, charting the percentage change of voluntary support over the previous year shows the relationship between the recessions and contributions (Figure 4). Losses in giving (or a negative percentage of change) occurred only in recessions or within one-year of a recession, where philanthropic giving might have lagged behind the economic recovery. There was one notable exception, fiscal year 1988-89. As discussed previously, understanding that individual giving is tied to the stock market (Arena, 2003), this anomaly could be explained by Black Monday, October 19, 1987, the second largest one-day percentage decline in the US stock market $(22.6$ percent) (Metz, 2003). While the stock 


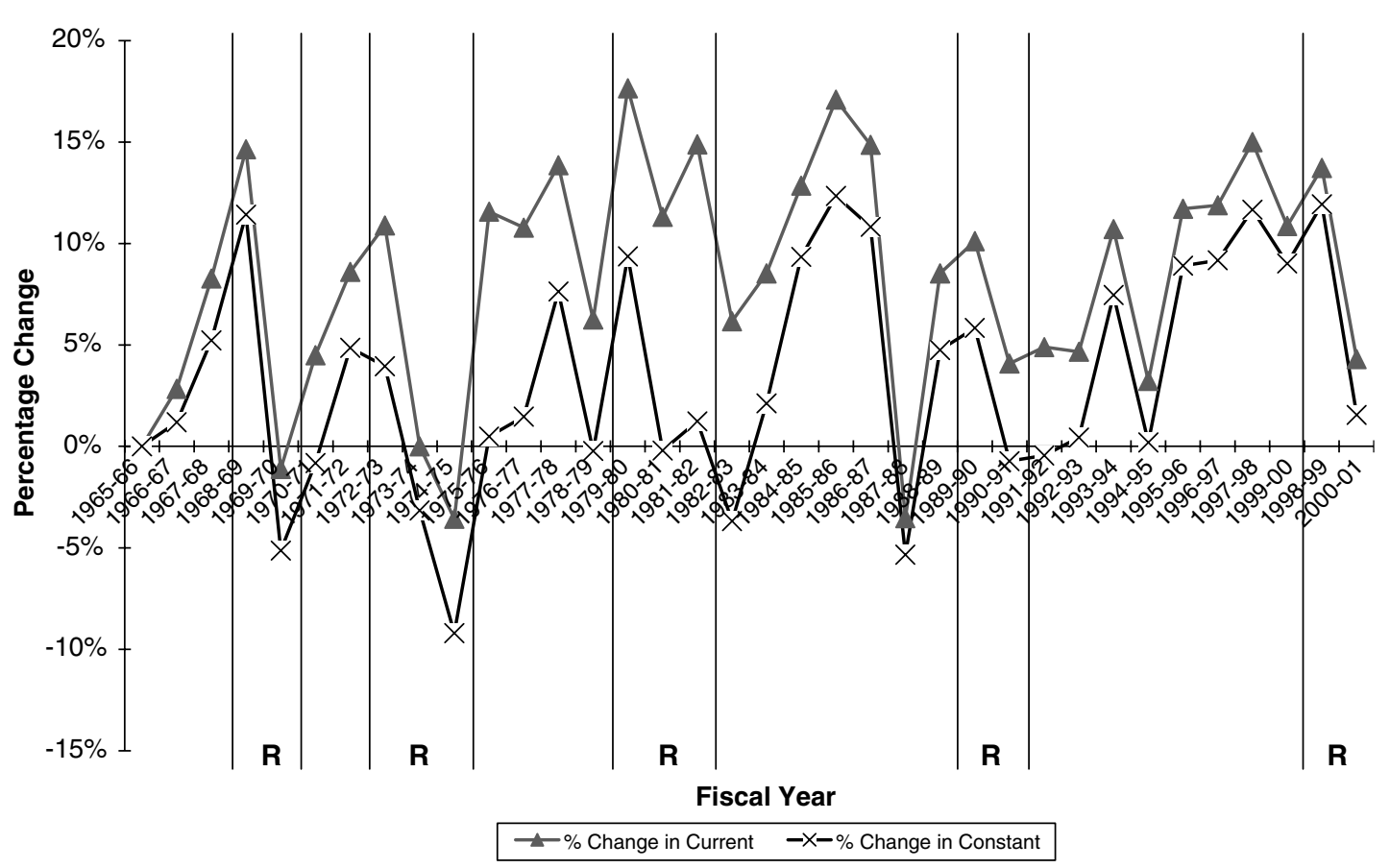

Figure 4: Percent change over previous year of voluntary support to higher education (AAFRC Trust, 1954-2005)

Note: ' $\mathrm{R}$ ' indicates periods of recessions in the US economy.

market began to recover, after this massive correction, the decline of giving to higher education in the following year could be associated with a phenomenon fund-raising professionals allude to among the largest donors called "psychic poverty," where economic uncertainty causes people to decrease their giving. Martin Grenzebach, chairman of Grenzebach, Glier, \& Associates, a campaign consulting firm, believes that "An extraordinary number of prospective donors [with a] net worth in excess of $\$ 5$-million are now [in economic downturns] feeling poor. They don't have the money, and don't have the optimism" (in Pulley, 2003). The "psychic poverty" phenomenon, while coined more recently might have been part of the reason that the decline in philanthropic giving to higher education lagged behind Black Monday by a full year.

\section{The Relationship between Tax Cuts on Philanthropic Giving}

Upon coming to office in 2001, George

W. Bush proposed massive tax cuts. The Economic Growth and Tax Relief Reconciliation Act of 2001 (Public Law No. 107-16) put into place several tax cuts including: marginal tax rate reductions, child tax credits, removal of marriage penalties, increases in the alternative minimum tax exemptions, reduction and eventual elimination of the estate taxes, and the creation of additional education incentives (KPMG, 2001). For 
example, under the current Bush tax cuts, the Act gradually lowers the maximum estate tax rate from 50 percent in 2002 to 45 percent by the year 2007, where it remains until 2010, when the estate tax is repealed. Additionally, the unified credit, which effectively exempts the majority of small- and medium-sized estates from federal estate taxes, gradually increases each year and by 2010. In other words, estates valued below $\$ 1$ million in 2002 were exempt from estate taxes; however, under the Economic Growth and Tax Relief Act of 2001, in 2009 all estates valued under $\$ 3.5$ million will be excused from estate taxes. With these two previsions, there is a concern that philanthropic bequests will decline as a result of a lower tax benefit available for gifts given at the time of death (Boskin, 1976; Joulfaian, 2000; Butler, 2001; Havens and Schervish, 2003). Because the current tax cuts are subject to a sunset provision, estate taxes could, however, be reinstated in 2011

(KPMG, 2001).

Critics of the Bush administration's tax cuts believe that the benefits primarily serve the wealthiest Americans. The nonpartisan Congressional Budget Office found that one-third of the provisions served people within the top 1 percent of earned income. Furthermore, the Congressional Budget Office found that two-thirds of the cuts went to the top fifth of household earners (Andrews, 2004). Those benefiting the most earned an average of $\$ 1.2$ million and received at $\$ 78,469$ tax cut, while families in the middle 20 percent of earnings $(\$ 57,000)$ only reduced their tax burden by $\$ 1,090$. In other words, the report found that "the average after-tax income for people in the top 1 percent of income earners climbed 10.1 percent, while that of those in the middle 20 percent climbed 2.3 percent, and that of those in the bottom fifth only 1.6 percent" (Andrews, 2004, p. 2).

Since the enacting of the Economic Growth and Tax Relief Reconciliation Act of 2001, overall philanthropic giving as a percentage of the GDP has declined by 8.7 percent, from 2.3 percent to 2.1 percent of the gross domestic product (Figure 2). Could this drop in giving be a result of the new tax legislation? Proponents of tax cuts might argue that with lower taxes individuals have more disposable income, resulting in more spending and higher charitable donations. Adversaries argue that with the wealthiest Americans receiving the greatest tax cuts, their personal tax incentives to donate to nonprofits will decrease the furthest. The Economic Growth and Tax Relief Act of 2001 effectively removed the charitable giving incentives from the wealthiest Americans. This is of particular concern to higher education where individual giving, both alumni and nonalumni combined, consistently accounts for nearly half of the overall giving to higher education (AAFRC Trust, 2005). Further, David Dunlop (2002), formerly a major gifts officer at Cornell University put forth the idea of a 20/80 rule in fund raising, where 20 percent of the individual donors give 80 percent of the money raised in a campaign. This rule has been revised through a study of the Council for the Advancement and Support of Education (CASE). A recent CASE survey found that while in fiscal year 2002, 1 percent of donors gave 69 percent of gifts, one year later 1 
percent gave 75 percent of dollars raised. When in a campaign to raise significant amounts of money the influence of the wealthy is even more staggering. In campaigns, institutions raised 89 percent of its contributions from only 10 percent of its donors in 2003 (CASE, 2004). This effectively changed Dunlop's 20/80 rule to a 10/90 tenet.

Understanding that individual giving is the majority of gifts to higher education and that the vast majority of these gifts are given by the wealthiest Americans, who as a result of the Bush tax cuts have a decreased tax incentive for giving, perhaps the decrease, since 2001 , in overall giving, both in real dollars (Figure 1) and as a percentage of gross domestic product (Figure 2) may be related to the Economic Growth and Tax Relief Reconciliation Act. Charitable tax deductions subsidize individual philanthropic giving by reducing the direct cost of making a contribution. For example, a donor in the 30 percent tax bracket (marginal tax) who gives $\$ 100$ to nonprofit reduces her federal tax obligation by $\$ 30$ when using the charitable tax deduction, effectively reducing the cost of her donation to $\$ 70$. In other words, allowable deductions in the simplest form are one minus the marginal tax.

There is, however, a general debate over whether or not charitable tax deductions stimulate giving (for further discussion see, Clotfelter and Steuerle, 1981; Clotfelter, 1990; Randolph, 1995, 1999; Barrett et al., 1997; Auten et al., 2000, 2002). Broadly, experts agree that donors are somewhat sensitive to the cost of giving and therefore would contribute more if the costs were less (Feldstein and
Clotfelter, 1976). Statistical studies of individual giving, conducted by Michael J. Boskin and Martin Feldstein (1977), found that giving was moderately sensitive to the after-tax cost of giving. Their study proposed that changes in tax rates, such as under the Bush tax cuts, that lowered the cost of giving could notably affect the amount taxpayers contribute to nonprofit organizations. Barrett et al. (1997) found, using a panel study of middle-class taxpayers, that while tax policy influences the level and time of donations, tax deductions for charitable giving are not treasury efficient. Therefore, changes in the marginal tax rate should not affect the size of philanthropic giving (Barrett et al., 1997).

The tax cuts enacted through the Tax Reform Act of 1986 (Public Law No. 99-514, 100 Stat. 2085), in which the marginal tax rate for the wealthiest Americans was decreased, effectively increased the after-tax cost of contributing by lowering their tax burden. For many citizens these tax cuts were significant (from 50 to 28 percent), thereby increasing the real cost of giving considerably, by 44 percent. For the first time in US income tax history, the Tax Reform Act of 1986, however, included an increase in the marginal tax rate for those in the lowest tax bracket at the same time it decreased the marginal tax rate for the wealthy. The increase for those in the lowest tax bracket was from 11 to 15 percent, in effect decreasing the after-tax cost of giving for those Americans by 36 percent. Based on the findings in the prior decade (Feldstein and Clotfelter, 1976), we would have expected to see an appreciable drop in overall giving after 
the enacting of the lower taxes in the upper tax brackets. This drop in donations did not materialize (Figure 1). Notably, with the exception of taxpayers in the highest federal tax brackets, philanthropic donations remained level. Those in the highest tax bracket decreased their philanthropic giving (Clotfelter, 1990).

Understanding how tax cuts effected philanthropic giving in the 1980 s we should be cautious to implicate tax cuts as the cause of the decline in giving. The fact that after the 1986 tax cuts donations by individuals in the highest tax brackets fell, coupled with the fact that overall giving in dollars is disproportionately contributed by those same individuals, demonstrated by the 10/90 tenet, is, however, very concerning.

\section{Wealth Transfer and the Repeal of Estate Taxes}

Also of note to philanthropic behavior is the repeal of the estate tax and its implication on wealth transfer and charitable bequests. John Havens and Paul Schervish note that over the next 55 years America will experience a "great wealth transfer" where \$41 trillion will likely be passed on from one generation to the next-through bequest, philanthropy, and taxes. A conservative estimate by Havens and Schervish approximates that of the "great wealth transfer" 15 percent, or $\$ 6$ trillion, will be given to nonprofit organizations (Havens and Schervish, 1999, 2003).

Havens and Schervish conducted their study in 1999 before the Bush tax cuts that proposed an elimination of estate taxes and the tax advantage for charitable giving at death. It is unclear how the $\$ 6$ trillion estimate will be affected by the tax cuts if they are adopted permanently. In a 1976 study Michael Boskin found through statistical modeling that estate taxes and the ability to deduct bequests from the taxable portion of ones assets at death positively affects giving through will provisions. In other words, these findings indicate that a decrease or repeal of estate taxes increases the cost of the bequest and would potentially decrease the number and size of philanthropic gifts given at death (Boskin, 1976).

David Joulfaian (2000), from the US Treasury Department, also found that the estate tax deduction given for charitable bequests is "budget efficient," in that it encourages giving at a rate higher than the revenue lost by the government. Joulfaian estimates in the absence of the estate tax, charitable bequests might decline by 12 percent. Stuart Butler (2001), citing Milton Friedman's permanent income/ overlapping generations theory, where a person's residual wealth (after heirs are taken care of) goes to philanthropic causes, however, believes that by eliminating the estate tax charitable bequests will increase since the after-tax cost of planned contributions to heirs would be reduced.

Steinberg et al. (2002) in a study at the Center on Philanthropy, using the Philanthropy Panel Study (COPPS) from the larger Panel Study of Income Dynamics, paints a bleak picture for the "great wealth transfer." They find "that the elasticity of giving from noninherited wealth is much greater than from inherited wealth ... although inherited wealth creates a higher marginal propensity to donate" (p. 1). 
In other words, Steinberg et al. (2002) agree with Avery (1994) that those who make their money are far more generous then those who inherit it. Using the marginal propensity to give (evaluated at the mean), the 2002 study finds that those who inherit wealth are 3.2 times less likely to give away their inherited wealth than their benefactors (Steinberg et al., 2002). Therefore, as the wealth transfer continues, annual giving to nonprofits will fall (Steinberg et al., 2002). This decrease will likely be greater with the adoption of the full estate tax repeal.

Like the tax cuts for living individuals, the effect of the estate tax repeal is very concerning and will not be fully understood without further economic modeling. Future research on the relationship between the Economic Growth and Tax Relief Reconciliation Act of 2001 and individual and bequest giving should be done, especially as Congress begins to decide whether or not to remove the sunset provisions to these tax laws, making them permanent.

\section{Conclusion}

Philanthropy's effect on higher education has been immense. Recently with dramatic increases in the cost to educate a student and decreases in state support for higher education and federal grant support, philanthropic dollars, both as current use and endowment, have an important role in helping maintain access to postsecondary education. Economic cycles contain times of prosperity and downturns. Better understanding recessions' relationship to philanthropy will help institutions better plan in advance for their fund-raising campaigns.
Giving to higher education is tightly connected to the economy and specifically to the stock market. There is, however, conflict as to how tax cuts such as the Economic Growth and Tax Relief Reconciliation Act of 2001 affects giving. While a good deal of information is already available to inform this discussion, more is needed. Human behavior is complex, and it is impossible to truly know intention and donor motivation to give. It is hard to figure out how much giving is done to avoid taxes, how much is based on a form of altruism and how much is a combination of the two.

Understanding, that charitable giving in the United States as a percentage of GDP has steadily declined since the enacting of the Bush tax cuts, future research is needed to understand if tax policy is responsible for the decline. The fact that the tax cuts benefit the wealthy disproportionately and that same population gives the most voluntary dollars to higher education, however, presents the rational for future study. Beyond the benefit to institutional leaders in knowing how recessions and tax cuts correlate with philanthropic giving this research will provide additional information to the government for use when deciding whether or not they should enact tax laws that might lower giving by the wealthiest people.

\section{Notes}

1 All inflation dollars and constant dollars were calculated using the Historical Statistics of the United States (Washington DC: The United States Government Printing Office, 1975) retrieved electronically from http:// www.westegg.com/inflation/; This 
website calculates US dollars in real values through use of the Consumer Price Index (CPI) statistics. 2 As of March 2005 there were 49 campaigns, either announced or completed, with goals over a billion dollars at institutions in the United States. In fact of the 49 campaigns, four universities (Johns Hopkins University, New York University, University of Michigan, and University of Virginia) are currently in the public phase of their second billion dollar-plus campaign (Capital campaign status, 2005). John Lippincott, president of the Council for the Advancement and Support of Education, predicts that in the near future "one or more institutions will announce \$5-billion campaigns ... the next psychological threshold to cross" (Strout, 2005).

\section{References}

American Association of Fundraising Counsel (1960), Giving USA 1960: The Annual Report on Philanthropy for the Year 1959, Author, New York.

American Association of Fundraising Counsel (1961), Giving USA 1961: The Annual Report on Philanthropy for the Year 1960, Author, New York.

American Association of Fundraising Counsel (1962), Giving USA 1962: The Annual Report on Philanthropy for the Year 1961, Author, New York.

American Association of Fundraising Counsel (1963), Giving USA 1963: The Annual Report on Philanthropy for the Year 1962, Author, New York.

American Association of Fundraising Counsel (1964), Giving USA 1964: The Annual Report on Philanthropy for the Year 1963, Author, New York.

American Association of Fundraising Counsel (1965), Giving USA 1965: The Annual Report on Philanthropy for the Year 1964, Author, New York.

American Association of Fundraising Counsel (1966), Giving USA 1966: The Annual Report on Philanthropy for the Year 1965, Author, New York.

American Association of Fundraising Counsel (1967), Giving USA 1967: The annual report on philanthropy for the year 1966, Author, New York.

American Association of Fundraising Counsel (1968), Giving USA 1968: The Annual Report on Philanthropy for the Year 1967, Author, New York.
American Association of Fundraising Counsel (1969), Giving USA 1969: The Annual Report on Philanthropy for the Year 1968, Author, New York.

American Association of Fundraising Counsel (1970), Giving USA 1970: The Annual Report on Philanthropy for the Year 1969, Author, New York.

American Association of Fundraising Counsel (1971), Giving USA 1971: The Annual Report on Philanthropy for the Year 1970, Author, New York.

American Association of Fundraising Counsel (1972), Giving USA 1972: The Annual Report on Philanthropy for the Year 1971, Author, New York.

American Association of Fundraising Counsel (1973), Giving USA 1973: The Annual Report on Philanthropy for the Year 1972, Author, New York.

American Association of Fundraising Counsel (1974), Giving USA 1974: The Annual Report on Philanthropy for the Year 1973, Author, New York.

American Association of Fundraising Counsel (1975), Giving USA 1975: The Annual Report on Philanthropy for the Year 1974, Author, New York.

American Association of Fundraising Counsel (1976), Giving USA 1976: The Annual Report on Philanthropy for the Year 1975, Author, New York.

American Association of Fundraising Counsel (1977), Giving USA 1977: The Annual Report on Philanthropy for the Year 1976, Author, New York.

American Association of Fundraising Counsel (1978), Giving USA 1978: The Annual Report on Philanthropy for the Year 1977, Author, New York.

American Association of Fundraising Counsel (1979), Giving USA 1979: The Annual Report on Philanthropy for the Year 1978, Author, New York.

American Association of Fundraising Counsel (1980), Giving USA 1980: The Annual Report on Philanthropy for the Year 1979, Author, New York.

American Association of Fundraising Counsel (1981), Giving USA 1981: The Annual Report on Philanthropy for the Year 1980, Author, New York.

American Association of Fundraising Counsel (1982), Giving USA 1982: The Annual Report on Philanthropy for the Year 1981, Author, New York.

American Association of Fundraising Counsel (1983), Giving USA 1983: The Annual Report on Philanthropy for the Year 1982, Author, New York.

American Association of Fundraising Counsel (1984), Giving USA 1984: The Annual Report on Philanthropy for the Year 1983, Author, New York.

American Association of Fundraising Counsel (1985), Giving USA 1985: The Annual Report on Philanthropy for the Year 1984, Author, New York.

American Association of Fundraising Counsel (1986), Giving USA 1986: The Annual Report on Philanthropy for the Year 1985, Author, New York.

American Association of Fundraising Counsel (1987), Giving USA 1987: The Annual Report on Philanthropy for the Year 1986, Author, New York. 
American Association of Fundraising Counsel (1988), Giving USA 1988: The Annual Report on Philanthropy for the Year 1987, Author, New York.

American Association of Fundraising Counsel (1989), Giving USA 1989: The Annual Report on Philanthropy for the Year 1988, Author, New York.

American Association of Fundraising Counsel (1990), Giving USA 1990: The Annual Report on Philanthropy for the Year 1989, Author, New York.

American Association of Fundraising Counsel (1991), Giving USA 1991: The Annual Report on Philanthropy for the Year 1990, Author, New York.

American Association of Fundraising Counsel (1992), Giving USA 1992: The Annual Report on Philanthropy for the Year 1991, Author, New York.

American Association of Fundraising Counsel (1993), Giving USA 1993: The Annual Report on Philanthropy for the Year 1992, Author, New York.

American Association of Fundraising Counsel (1994), Giving USA 1994: The Annual Report on Philanthropy for the Year 1993, Author, New York.

American Association of Fundraising Counsel (1995), Giving USA 1995: The Annual Report on Philanthropy for the Year 1994, Author, New York.

American Association of Fundraising Counsel (1996), Giving USA 1996: The Annual Report on Philanthropy for the Year 1995, Author, New York.

American Association of Fundraising Counsel (1997), Giving USA 1997: The Annual Report on Philanthropy for the Year 1996, Author, New York.

American Association of Fundraising Counsel (1998), Giving USA 1998: The Annual Report on Philanthropy for the Year 1997, Author, New York.

American Association of Fundraising Counsel (1999), Giving USA 1999: The Annual Report on Philanthropy for the Year 1998, Author, New York.

American Association of Fundraising Counsel (2000), Giving USA 2000: The Annual Report on Philanthropy for the Year 1999, Author, New York.

American Association of Fundraising Counsel (2001), Giving USA 2001: The Annual Report on Philanthropy for the Year 2000, Author, New York.

American Association of Fundraising Counsel (2002), Giving USA 2002: The Annual Report on Philanthropy for the Year 2001, Author, New York.

American Association of Fundraising Counsel (2003), Giving USA 2003: The Annual Report on Philanthropy for the Year 2002, Author, New York.
American Association of Fundraising Counsel 2004), Giving USA 2004: The Annual Report on Philanthropy for the Year 2003, Author, New York.

American Association of Fundraising Counsel (2005), Giving USA 2005: The Annual Report on Philanthropy for the Year 2004, Author, New York.

Andrews, E.L. (2004, August, 13), "Report finds tax cuts heavily favor the wealthy," New York Times, Retrieved Electronically on April 1, 2006 from http://www.nytimes.com/2004/08/13/ politics/campaign/13tax.html?ex=1250136000\& en $=6 \mathrm{f} 84660636 \mathrm{ae} 70 \mathrm{~cd} \& \mathrm{ei}=5090 \&$ partner $=\mathrm{rssu}$ serland.

Arena, R. (2003 13, Winter), “Firm's comprehensive study reveals emerging trends in giving," Marts \& Lundy Counsel, 2003 volume. Retrieved Electronically on April 1, 2006 from http://www.martsandlundy. com/atf/cf/\% 7B7606E449.261E-435C-AA98AEBBD43329BE\%7D/2003Winter.pdf.

Ashcraft, R.F. (1995), "An analysis of alumni donation and nondonation related to selected personal, involvement and outcome factors", Ph.D. dissertation, Arizona State University.

Auten, G., Sieg, H. and Clothfelter, C. (2002, March), "Charitable giving, income, and taxes: An analysis of panel data," American Economic Review, 92, (1), pp. 371-383.

Auten, G.E., Clotfelter, C.T. and Schmalbeck, R.L. (2000), "Taxes and Philanthropy Among the Wealthy," in J. Slemrod (ed.), Does Atlas Shrug: The Economic Consequences of Taxing the Rich, Russell Sage and Harvard University Press, New York.

Avery, R. (1994), "The pending intergenerational wealth transfer," Philanthropy, III, (1), pp. 28-29.

Barrett, K.S., McGuirk, A.M. and Steinberg, R. (1997, June, 19), "Further evidence on the dynamic impact of taxes on charitable giving," National Tax Journal, L (2), pp. 321-334.

Boskin, M.J. (1976), "Estate taxation and charitable bequests," Journal of Public Economics, V, pp. 27-56.

Boskin, M.J. and Feldstein, M. (1977, August), "Effects of the charitable deduction on contributions by low income and middle income households: Evidence from the national survey of philanthropy," The Review of Economics and Statistics, 59, (3), pp. 351-354.

Browar, L. and Streit, S.A. (2003), "Mutually assured survival: Library fund-raising strategies in a changing economy," Library Trends, 52, (1), pp. 69-86.

Butler, S.M. (2001, March, 8), "Why the Bush tax cuts are no threat to philanthropy," The Heritage Foundation Backgrounder, Retrieved Electronically on March 30, 2006 from http:// www.heritage.org/research/taxes/bg1417.cfm. 
Capital campaign status (2005), The Chronicle on Higher Education. Retrieved April 5, 2005 from the World Wide Web: http://www.chronicle. com/prm/weekly/campaigns/.

Clotfelter, C.T. (1990), "The impact of tax reform on charitable giving: A 1989 perspective," in J. Slemrod (ed.), Do Taxes Matter: The Impact of the Tax Reform Act of 1986, MIT Press, Cambridge, MA.

Clotfelter, C.T. and Steuerle, C.T. (1981), "Charitable contributions," in H. J. Aaron and J. A. Pechman (eds.), How Taxes Affect Economic Behavior, Brookings Institution, Washington, D.C.

Council for the Advancement and Support of Education (2004, October), The CASE Report of Educational Fundraising Campaigns: 20022003, Author, Washington, DC.

Council for Financial Aid to Education (1973), Volunteerism, Tax Reform, and Higher Education, Author, New York, NY.

Council of Economic Advisers (2000), Philanthropy in the American Economy: A Report by the Council of Economic Advisers, Clinton White House, Washington, DC. Retrieved on March 28, 2006 from http://clinton4.nara.gov/media/ pdf/philanthropy.pdf.

Curti, M. and Nash, R. (1965), Philanthropy in the Shaping of American Higher Education, Rutgers University Press, New Brunswick, NJ.

Cutlip, S.M. (1965), Fund Raising in the United States, Rutgers University Press, New Brunswick, NJ.

Dunlop, D. (2002), "Major gift programs," in M. J. Worth (ed.), New Strategies for Educational Fund Raising, Prager, Westport, CT, pp. 89-105.

Duronion, M.A. and Loession, B.A. (1991), Effective Fund Raising in Higher Education, Jossey-Bass, San Francisco, CA.

Feldstein, M. and Clotfelter, C. (1976), "Tax incentives and charitable contributions in the United States," Journal of Public Economics, V, pp. 1-26.

Foundation Center (2002), "Giving USA estimates total charitable giving at $\$ 212$ billion in 2001," Philanthropy News Digest. Retrieved on April 2, 2006, from http://fdncenter.org/newsletters.

Garvin, Jr, C.C. (1978), Corporate Philanthropy: The Third Aspect of Social Responsibility, Council for Financial Aid to Education, New York.

Gaudiani, C. (2003), The Greater Good, Times Books, New York.

Hall, P.D. (1992, Spring), "Teaching and research on philanthropy, voluntarism, and nonprofit organizations: A case study of academic innovation," Teachers College Record, 93, (3), pp. 403-436.
Havens, J.J. and Schervish, P.G. (1999), Millionaires and The Millennium: New Estimates of the Forthcoming Wealth Transfer and the Prospects for a Golden Age of Philanthropy, Boston College Social Welfare Research Institute, Boston.

Havens, J.J. and Schervish, P.G. (2003), "Why the \$41 trillion wealth transfer estimate is still valid: A review of challenges and questions," The Journal of Gift Planning, 7, (1), pp. 11-15.

Joulfaian, D. (2000), Estate Taxes and Charitable Bequests by the Wealthy, Working paper No. 7663. National Bureau of Economic Research, Cambridge, MA.

KPMG (2001), The Economic Growth and Tax Relief Reconciliation Act of 2001, Author, New York. Retrieved electronically on April 2, 2006 from http://www.us.kpmg.com/microsite/ taxnewsflash/2001/TaxBook/2001TaxBill.pdf.

Metz, T. (2003), Black Monday: The Stock Market Catastrophe of October 19, 1987, Bcard Books, Frederick, Maryland.

Meuth, E.F. (1992), "Corporate philanthropy in American higher education: An investigation of attitudes towards giving”, Ed.D. dissertation, The University of Akron.

Pulley, J.L. (2002, July, 5), "Charitable giving to education suffered in 2001, report says," The Chronicle of Higher Education, p. A27.

Pulley, J.L. (2003, Febraury, 28), "Struggling against the tide," Chronicle of Higher Education, 49, (25), retrieved electronically from EBSCO MegaFILE.

Randolph, W.C. (1995, August), "Dynamic income, progressive taxes, and the riming of charitable contributions," Journal of Political Economy, 103, (4), pp. 709-738.

Randolph, W.C. (1999), "Charitable deductions," in J. J. Cordes, R. D. Ebel, J. G. Gravell (eds.), The Encyclopedia of Taxation and Tax Policy, Urban Institute Press, Washington, D.C.

Rudolph, F.J. (1962), The American College and University: A History, Vintage Books, New York.

Steinberg, R., Wilhelm, M., Rooney, P. and Brown, E. (2002), Inheritance and Charitable Donations, Working paper, Center on Philanthropy at Indiana University, Indianapolis.

Strom, S. (2002, October, 11), "Cultural groups and charities are feeling each bump on Wall Street," The New York Times, p. A27.

Strout, E. (2005, January, 7), "Fund raising: The big gifts had better get bigger," The Chronicle of Higher Education, 51, (18).

Van Der Werf, M., Blumenstyk, G. and June, A.W. (2002 August, 9), "Fallout from Wall Street hits colleges hard," The Chronicle of Higher Education, p. A27. 